\title{
Cascading effect of exotic fish fry on plankton community in a tropical Andean high mountain lake: a mesocosm experiment
}

\author{
Yimy HERRERA-MARTÍNEZ,, $2^{1 *}$ Juan César PAGGI, ${ }^{3}$ Camilo Bernardo GARCIA ${ }^{1}$
}

${ }^{1}$ Doctorado en Ciencias-Biología, Departamento de Biología, Facultad de Ciencias, Universidad Nacional de Colombia, 111321 Bogotá DC, Colombia; ${ }^{2}$ Grupo de Investigación, Manejo integrado de Ecosistemas y Biodiversidad - XIUÂ, Escuela de Ciencias Biológicas, Universidad Pedagógica y Tecnológica de Colombia - UPTC, Avenida Central del Norte 39-115, 150003 Tunja, Colombia; ${ }^{3}$ Instituto Nacional de Limnología, Consejo Nacional de Investigaciones Científicas y Técnicas - Universidad Nacional del Litoral, Ciudad Universitaria, 3000 Santa Fe, Argentina

*Corresponding author: yimyherrera@yahoo.com

\begin{abstract}
Fishless Andean high mountain lakes may be vulnerable to fish invasion because they tend to be small, oligotrophic and contain low zooplankton diversity. During the first decades of the twentieth century, rainbow trout, Oncorhynchus mikiss, was introduced in South America, and stocking of juvenile stages (fry) in lakes continues today. However, their effect on plankton in these lakes has been little studied. We performed a mesocosms experiment to assess effects of trout of different ontogenetic stages on zooplankton and phytoplankton in a tropical-Andean high mountain lake. The presence of trout fry resulted in declines in several large zooplankton taxa, increases in chlorophyll $a$ and dissolved inorganic nitrogen (DIN). Our results showed that small fry consume large copepods (Colombodiaptomus brandorffi) at a faster rate than larger fry, and also consumed medium sized copepods (Tropocyclops prasinus) that are not affected by the larger trout fry. Fish of both sizes consumed Ceriodaphnia quadrangula, a midsize cladoceran. Fish predation had weak effect on the phytoplankton biomass, but we found a correlation between zooplankton biomass and phytoplankton richness, and significantly larger cell of the alga Peridinium in the presence of fish. Our results indicate that trout introduction produces cascading ecological and phenotypic effects on the plankton communities of tropical mountain lakes, similar to those observed in temperate latitudes.
\end{abstract}

Key words: Introduced species; predation; crustaceans; zooplankton; phytoplankton; trout fry.

Received: April 2016. Accepted: January 2017.

\section{INTRODUCTION}

Most of the tropical high mountain lakes in South America are small, oligotrophic and either fishless. The few that present fish, habitually possess a single species, usually endemic. Among these endemic species Rhizosomichthys totae (Miles, 1942) is considered to be extinct due to introduction of rainbow trout (Oncorhynchus mykiss, Walbaum 1792) in Lake Tota (Acero, 1977; Hernández et al., 1992; Mora et al., 1992). O. mykiss was introduced in Colombia in the second decade of the last century (Welcomme, 1988). The introduction of non-native species occupying higher trophic levels can cause impacts through predation, competition, hybridization, diseases and habitat degradation (Pace et al., 1999; Davis, 2003; Hickley and Chare, 2004; Gallardo et al., 2015). Introduced salmonids exert strong control over lake food webs and water quality (Crawford and Muir, 2008; Strayer, 2010), leading to loss of biodiversity in the lakes (Gliwicz and Rowan, 1984; Donald et al., 2001; Sarnelle and Knapp, 2004). O. mykiss has spread widely across all continents (Crawford and Muir, 2008) and is considered one of the hundred most harmful introduced species globally (Lowe et al., 2000). Introduction of $O$. mykiss has been shown to cause cascading effects on zooplankton, phytoplankton, benthic invertebrates and nutrient cycling (Knapp et al., 2001a; Schindler et al., 2001). Studies on the effect of exotic fish such as rainbow trout in tropical high mountain lakes of South America are scarce. Mora et al. (1992) found that the diet of O. mykiss on Lake Tota in Colombia is dominated by a characid fish and Daphnid cladocerans. However, consequences of fish introduction for Andean lake ecosystem structure and function are largely unknown.

The cascading effects of fish predation on primary producers via zooplankton, as demonstrated from the pioneering works of Hrbáček et al. (1961) and Brooks and Dodson (1965), has become one of the dominant paradigms of aquatic ecology (Brett and Goldman, 1996; MacLennan et al., 2015). However, the effects of fish vary among lake ecosystems and geographic regions depending on factors such as differences in life history of fish (Post et al., 2008), ontogenetic changes (Balon, 1984; Modenutti et al., 1993; Mehner and Thiel, 1999; Blair et 
al., 2012), biotic structure of ecosystems (Werner and Gilliam, 1984; Pujoni et al., 2016), and climate (Kratina et al., 2012). The study of Aguilera et al. (2006) conducted in the tropical high Andes, suggested that trout have a 'top-down' effect on plankton, but raised the need for experimental work to assess the impact of trout in the lakes of this region.

O. mykiss, like most salmonids, varies in diet depending on their stage of development and the availability of prey (Werner and Gilliam, 1984; Oscoz et al., 2005). Modenutti et al. (1993) found a relationship between the state of development of the fish and the size of the prey in a lake to the south of the Andes. The diet of rainbow trout in Andean lakes of Argentine Patagonia varied in relation to the biotic composition of each lake (Ribeiro Guevara et al., 2006; Juncos et al., 2011). However, most studies on the diet of rainbow trout in lakes have been conducted mainly on fish which are caught with gill nets (Mora et al., 1992; Budy et al., 2005; Buktenica et al., 2007) which rarely catch fish $<150 \mathrm{~mm}$. The diets of juvenile and larval fish in South American lakes are therefore unknown. O. mykiss enter lakes from streams in the juvenile stage at younger ages than other salmonids (Graynoth, 1999). Therefore, the effect of juvenile trout on plankton can be greater than that of adults, as shown by Ban et al. (2013).

In this study, we sought to determine the effect of two sizes of $O$. mykiss fry on zooplankton in a tropical Andean high mountain lake. Our goal was to determine the relationship between the size of fry and that of their prey, and whether the impact of predation is transmitted via a cascade to phytoplankton and nutrient concentrations. For this purpose, nine experimental mesocosms were installed in a natural fishless lake. We imposed three experimental treatments (control, large fry, small fry) and measured the composition of the phytoplankton and zooplankton communities over 20 days.

\section{METHODS}

\section{Study area and experimental design}

Experiments were carried out in mesocosms built in the fishless Lake Cristalina of $0.014 \mathrm{~km}^{2}\left(5^{\circ} 57^{\prime} \mathrm{N}, 73^{\circ} 05^{\prime} \mathrm{E}\right)$, located in the paramo La Rusia at $3740 \mathrm{~m}$ asl. This paramo, along with those of Belen and Guantiva, form a continuum of about $56 \mathrm{~km}$ in length (Arellano and Rangel, 2008) which is part of Corridor Iguaque - La Rusia - Guantiva, a mountainous subsystem in the Eastern Cordillera Colombia. The paramo La Rusia is considered semi-wet (Rangel and Aguilar, 1995) and the area around the Lake Cristalina is dominated by grasses of Calamagrostis effusa Kunth which is mixed with low shrubs and frailejones as Espeletiopsis guacharaca Díaz (Cuatrecasas, 1996; DíazPiedrahita and Rodríguez-Cabeza, 2008).
Before installing the mesocosms, in the deepest part of the lake (approximately $9 \mathrm{~m}$ ) a platform was installed, near the center of the lake to provide support for the mesocosms and conditioning cages. The platform (width $=1.0$ $\mathrm{m}$, length=4.0 m), was built of wood and supported on sealed plastic tanks and anchored with steel cables to four poles buried in shallow waters. The fry were placed in two floating cages for at least 2 days before starting the experiments, in order to acclimatize them to the environment of the lake. The mesocosms were fabricated with low-density clear polyethylene (LDPE). We constructed bags of $1.6 \mathrm{~m}$ in diameter and $1.8 \mathrm{~m}$ long, open on both sides, which were placed in the lake for three months, before the start of the experiments, with the purpose of removing any harmful substance adhered to LDPE. Prior to the start of the experiments, we washed the LDPE bags with water from the lake to remove particles and organisms attached. With the bags, we build nine mesocosms of about $3.0 \mathrm{~m}^{3}$, $1.5 \mathrm{~m}$ deep, closed bottom; supported by floating rings made from tube polyvinyl chloride (PVC) and expanded polystyrene (EPS) (Fig. 1). We built nine hexagonal PVC and HDPE cages of $1.6 \mathrm{~m}$ height and $1.4 \mathrm{~m}$ in diameter with holes of approximately $6 \mathrm{~mm}$, which were placed inside each of the mesocosms in order to contain the fish. The mesocosms were filled systematically with lake water filtered through a $75 \mu \mathrm{m}$ mesh plankton net to remove zooplankton using a pump from a boat. The entry of nauplii during filling was unlikely since the smaller nauplii that were measured had around $100 \mu \mathrm{m}$. Mesocosms were acclimatized for one day before starting the experiment.

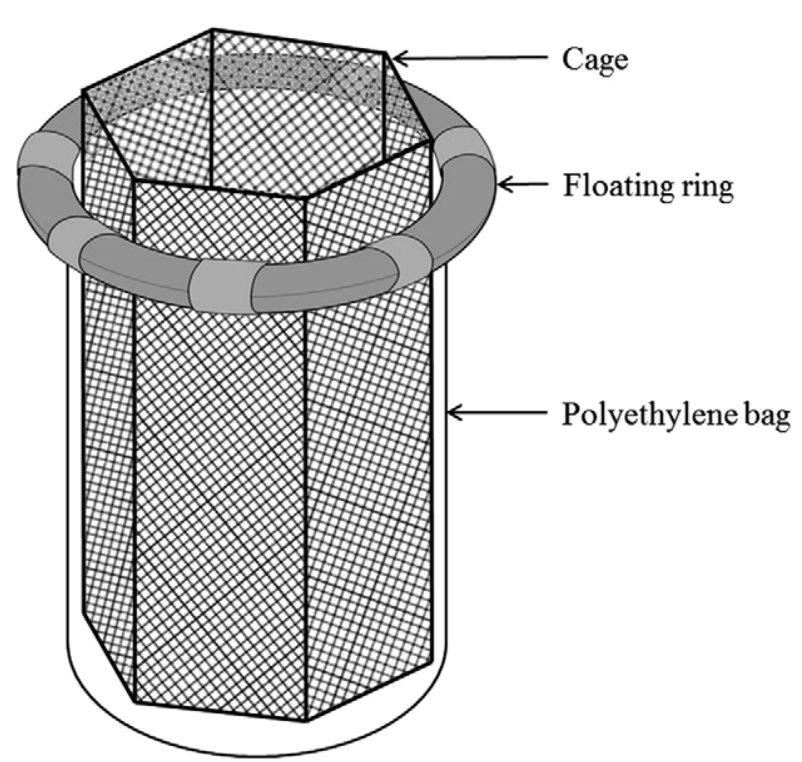

Fig. 1. Example of the mesocosms constructed for the realization of the experiments. 
We collected the lake zooplankton with a net $(75-\mu \mathrm{m}$ mesh, $30 \mathrm{~cm}$ diameter) by vertical and horizontal hauls. The zooplankton were put in a plastic container of 14 liters, homogenized permanently and during the agitation was taken a liter of water with zooplankton that was incorporated to each mesocosm. For the experiment, we assigned the mesocosms to three treatments with three replicates each: Control without fish fry (control), large trout fry (LTF) and small trout fry (STF). In the LTF we placed 25 trout of $4.6 \mathrm{~cm}$ of average standard length and in STF 75 trout of $3.7 \mathrm{~cm}$ of average standard length, with an average biomass between $50-60 \mathrm{~g}$ per mesocosm. All mesocosms were covered with a net at the surface to prevent fish from escaping. The fry were obtained from the fish farm 'Truchas de la Sierra' located in Guasca (Cundinamarca, Colombia), which imports eggs of rainbow trout (Oncorhynchus mykiss) from the United States. The experiment was conducted for 20 days between 20 February and 12 March 2013. During this period, the mesocosms were examined twice daily to make sure they were in good condition. The mesocosms were sampled for physico-chemical and biological analysis on days $0,4,8$, 13 and 20. All mesocosms were sampled at T0, immediately before introducing fish. Before taking samples, mesocosms were mixed for 5 minutes with a paddle. At the end of the experiment the cages were carefully removed from the mesocosms and all fish were extracted from the cages and counted. We checked that all the fish were recovered. Then we removed the mesocosms from the water.

\section{Sampling and analysis of crustacean zooplankton}

Crustacean zooplankton were sampled by vertical hauls from the bottom to the surface of the mesocosms with a plankton net (75- $\mu \mathrm{m}$ mesh, $30 \mathrm{~cm}$ diameter), we preserved the samples following a procedure modified from Haney and Hall (1973). Soda water was added to each sample to narcotize the organisms and preserved in $4 \%$ formalin with Rose Bengal stain. Each net drag represented approximately $3 \%$ of the total volume of each mesocosm, which could have an effect on the data; however, the control mesocosms indicate that the effect was low and that the results are attributable largely to the effect of the fishes. Specimens were identified to species when possible using a microscope light at 400x magnification based on the guides of Smirnov (1971), Reid (1985), Gaviria (1989), Paggi (1995), Elmoor-Loureiro (1997) and Elías-Gutiérrez et al. (2008). Samples were counted in their entirety. Crustacean zooplankton were counted using a 7-mL-capacity Bogorov chamber under stereo microscope at 10x and 100x magnification. The chamber Bogorov was made with Poly(methyl methacrylate) (dimensions $9 \times 11.5 \times 0.6 \mathrm{~cm}$ ) with $40-\mathrm{cm}$ sinuosity-long and $0.5-\mathrm{cm}$ wide. The total lengths of 40 specimens of each abundant taxon were measured, while all specimens found were measured for the scarce taxa. Biomass of each taxon was estimated using length-mass regressions (Dumont et al., 1975).

\section{Sampling and analysis of phytoplankton}

Water samples of $1 \mathrm{~L}$ for phytoplankton were taken with a vertical sampler from the bottom to the surface of each mesocosm. The vertical sampler was made with 4-m transparent PVC hose of $1.8 \mathrm{~cm}$-diameter with a foot valve at the bottom and a removable cap at the top. The samples were fixed with Lugol's Iodine solution and phytoplankton cells were identified to genus, and morphotypes within each genus were differentiated when possible. Counts were performed according to Utermöhl (1958). Each sample was placed in a sedimentation chamber for at least $24 \mathrm{~h}$ and then enumerated at 200x and 400x magnification using an inverted microscope. Thirty cells of each algal morphotype were measured and the biovolume was estimated using the geometric formulas of Hillebrand et al. (1999) and Sun and Liu (2003). To calculate phytoplankton biomass, algal biovolume was converted to wet weight (WW) assuming a specific gravity of $1.0 \mathrm{~g} \mathrm{~cm}^{-3}$ (Rott, 1978), and dry weight (DW) was calculated using DW:WW ratio of 0.29 (Jeppesen et al., 1994). The mean greatest axial linear dimension (GALD) of each phytoplankton taxon was determined and the fraction of biomass for algae with GALD $\leq 30 \mu \mathrm{m}$ and GALD $>30 \mu \mathrm{m}$ were calculated for each sample. We calculated the diversity index of Shannon (H') (Shannon and Weaver, 1963), and the ratio of zooplankton biomass to phytoplankton biomass (BZ:BP) was used as an indicator for the herbivory pressure of the zooplankton on the phytoplankton (Vijverberg et al., 2014; Maclennan et al., 2015).

\section{Physical and chemical analysis}

Water samples of $1.0 \mathrm{~L}$ were taken with the vertical sampler for physico-chemical analysis. Temperature (TEM), $\mathrm{pH}$, oxygen saturation $\left(\mathrm{O}_{2} \mathrm{~S}\right)$, conductivity (CON) and alkalinity (ALK) were measured in situ. TEM and $\mathrm{pH}$ were measured with $\mathrm{pH}$ meter WTW-3210, $\mathrm{O}_{2} \mathrm{~S}$ with YSI-55 meter and CON with YSI-30 meter. ALK was calculated with a method based on the function of Gran (1950) and using the Alcagran program developed by Carmouze (1994). The water samples were analyzed for dissolved inorganic nitrogen (DIN: $\mathrm{NH}_{4}-\mathrm{N}$ $\left.+\mathrm{NO}_{3}-\mathrm{N}+\mathrm{NO}_{2}-\mathrm{N}\right)$, dissolved reactive phosphorus (DRP: $\left.\mathrm{PO}_{4}-\mathrm{P}\right)$, organic matter (OM) and chlorophyll $a$ (CLOR $a$ ). $\mathrm{NH}_{4}, \mathrm{NO}_{3}, \mathrm{NO}_{2}$ and $\mathrm{PO}_{4}$ according to standard methods (Clesceri et al., 1998; Rice et al., 2012). OM was determined by oxidation with potassium permanganate $\left(\mathrm{KMnO}_{4}\right)$ (Rodier, 1990; Rodier et al., 2011). 
CLOR $a$ was analyzed using a modified procedure from Nusch (1980) and Sartory and Grobbelaar (1984). Between 250 and $2000 \mathrm{~mL}$ water were filtered through glass fiber filters $(\mathrm{GF} / \mathrm{C})$, which were kept in aluminum foil and were stored at $-20^{\circ} \mathrm{C}$. Subsequently, each filter was placed in a test tube with $5 \mathrm{~mL}$ of hot $95 \%$ ethanol, heated at $75^{\circ} \mathrm{C}$ in a water bath for $2.5 \mathrm{~min}$, and then remained for $24 \mathrm{~h}$ in the dark at room temperature. Each filter was drained and $5 \mathrm{~mL}$ of $95 \%$ ethanol was added to the extract. The extract was centrifuged at $5000 \mathrm{rpm}$ for $15 \mathrm{~min}$ and the absorbance was measured at 665 and $750 \mathrm{~nm}$, then $0.1 \mathrm{~N} \mathrm{HCl}$ was added and the absorbance was measured again. The final concentration of chlorophyll $a$ was calculated using the formula:

$$
\begin{gathered}
{[\text { Chlorophyll } a]=} \\
29.6\left(\left(\mathrm{~A}_{665}-\mathrm{A}_{750}\right)-\left(\mathrm{Aa}_{665}-\mathrm{Aa}_{750}\right)\right)\left(v /\left(V^{*} L\right)\right)
\end{gathered}
$$

Where: $v$ is the volume of the extract $(10-\mathrm{mL}), V$ the volume of the filtered sample (in liters), $\mathrm{A}_{665}$ and $\mathrm{A}_{750} \mathrm{ab}-$ sorbance unacidified, $\mathrm{Aa}_{750}$ and $\mathrm{Aa}_{665}$ absorbance after acidification and $L$ the length of the quartz cuvette $(\mathrm{cm})$.

\section{Data processing}

Biological data were transformed by $\log _{10}(\mathrm{X}+1)$ to homogenize the variances. When the variables were found to be significantly skewed or heterogeneity of variance was evident after transformation, non-parametric tests for treatment effects were used. The significance of differences in the zooplankton biomass among treatments was assessed with ANOVA for repeated measures using the RWizard 1.1 application (Guisande et al., 2014) to the program $\mathrm{R}$ ver. 3.2.1. The repeated measures analysis was applied to observe responses in time of correlated data and comply with the assumption of equal variances between each two levels of the factor of repeated measurements, that is the variance-covariance matrix is spherical (Huynh and Feldt, 1970). To determine the sphericity was used Mauchly's test (Mauchly, 1940). When the sphericity hypothesis was rejected, indicating that the $F$ reason statistic of the ANOVA was biased (Box, 1954a, 1954b), the degrees of freedom were corrected using the correction factor epsilon $(\mathcal{C})$ (Box, 1954a, 1954b) and a new probability was calculated. Two estimates of $\varepsilon$ were made, Greenhouse and Geisser (1959) and Huynh and Feldt (1970), selecting the highest value.

The correlations between variables were examined using the Pearson correlation coefficient $(r)$ and the Spearman rank coefficient $\left(r_{s}\right)$ depending on the normality of the data. The GALD of Peridinium (the most abundant phytoplankton taxon) at T0 y T4 in the three treatments were compared with the Kruskal-Wallis ANOVA (Kruskal and Wallis, 1952) and Wilcoxon-Mann-Whitney test using the functions kruskal.test and wilcox.test, respectively, for
R with RWizard 1.1 (Guisande et al., 2014).

\section{RESULTS}

\section{Environmental variables}

During the course of the experiment the water was acidic ( $\mathrm{pH} 4.8$ to 5.3), slightly mineralized (conductivity 8.3 to $\left.9.1 \mu \mathrm{S} \mathrm{cm} \mathrm{cm}^{-1}\right)$, alkaline $\left(-19.3-3.2 \mu \mathrm{Eq} \mathrm{L}^{-1}\right)$ and with low concentrations of DRP (0.0 to $\left.32.0 \mu \mathrm{g} \mathrm{P} \mathrm{cm}^{-1}\right)$ and DIN ( 0.0 to $42.2 \mu \mathrm{g} \mathrm{N} \mathrm{cm}^{-1}$ ). Daytime water temperature was between 11.5 to $13.6^{\circ} \mathrm{C}$, with high oxygen saturation (72.8 - 93.6\%) and chlorophyll $a$ from 0.0 to 10.7 $\mathrm{mg} \mathrm{L}^{-1}$. All environmental variables varied over time (ANOVA $\mathrm{P}<0.01$ ) in all treatments (Tab. 1, Fig. 2). Chlorophyll $a$ increased in both treatments with fry (LTF and STF) but not in the control treatments (Tab. 1, Fig. 2 ), and was correlated negatively with the biomass of Colombodiaptomus brandorffi Gaviria, 1989 ( $\mathrm{r}=-0.79$, $\mathrm{P}<0.001)$. The DIN increased between days 0 and 8 in fry treatments and then decreased between days 8 and 20 (Tab. 1, Fig. 2).

The presence of fish had a positive effect (ANOVA $\mathrm{P}<0.005$ ) on concentrations of DIN and chlorophyll $a$; however, the decrease of DIN in the mesocosms with fishes at the end of the experiment was possibly caused by algal uptake, reflected in the increased chlorophyll $a$. Other water chemistry variables showed no differences between treatments. No differences in environmental variables were found between the two treatments with trout fry (Tab. 1, Fig. 2).

\section{Zooplankton}

We found ten species of crustacean zooplankton in the Lake Cristalina. The calanoid C. brandorffi was the largest (LT $908 \mu \mathrm{m}$ ) and most abundant species, contributing 97\% of the total average biomass at the beginning of the experiment. Two medium-sized species, the cladoceran Ceriodaphnia quadrangula s.l. (O.F. Müller, 1785) (LT $587 \mu \mathrm{m}$ ) and the cyclopid copepod Tropocyclops prasinus s.l. (Fischer, 1860) (LT $647 \mu \mathrm{m})$ accounted for 1.2 and $0.8 \%$ respectively of the initial biomass. Small cladocerans (mainly Bosmina and Chydoridae with $\mathrm{TL}<500 \mu \mathrm{m}$ ) and nauplii, each represented less than $0.1 \%$ of the biomass. Throughout the course of the experiment the biomass of C. brandorffi and $C$. quadrangula decreased significantly in the fish treatments (STF and LTF), but not in the control treatments (ANOVA $\mathrm{P}<0.001$ ) (Tab. 1), likely as a result of trout fry predation on these two species of crustaceans (Fig. 3). However, the STF reduced the biomass of C. brandorffi faster than the LTF, indicating higher rates of consumption by smaller fish (Fig. 3). T. prasinus biomass decreased in mesocosms with STF (ANOVA $\mathrm{P}<0.005$ ), but not in LTF and showed no clear trend in the control (Tab. 1, Fig. 3). 
Small cladocerans and nauplii were not affected by predation (Tab. 1). C. quadrangula was the only species to increase in controls (Fig. 3).

\section{Phytoplankton}

Large algae with GALD $>30 \mu \mathrm{m}$ dominated the phytoplankton biomass, and Peridinium was the most abundant genus $(90.4 \%$ of the total biomass). Biomass with GALD $>30 \mu \mathrm{m}$ increased and biomass with GALD $\leq 30$ $\mu \mathrm{m}$ decreased in all treatments. However, the increase of GALD $>30 \mu \mathrm{m}$ was greater in treatments with trout fry, and not significantly different between LTF and STF (although greater on average in LTF, Fig. 4, Tab. 1). Phytoplankton biomass, including those with GALD $>30 \mu \mathrm{m}$, showed a positive correlation with chlorophyll $a(0.51$ and 0.52, respectively, $\mathrm{P}<0.001)$. Biomass of phytoplankton with GALD $>30 \mu \mathrm{m}$ showed negative correlation with $C$. brandorffi $(=-0.39, \mathrm{P}<0.001)$ and $\mathrm{DRP}(-0.57, \mathrm{P}<0.001)$.

We identified 75 algal morphotypes belonging to 43 genera of eight taxonomic orders. The diversity decreased over time in LTF and STF treatments and remained almost constant in control. Phytoplankton richness decreased when GALD $>30 \mu \mathrm{m}$ increased $(-0.54, \mathrm{P}<0.001)$ and zooplankton biomass decreased $(0.43, \mathrm{P}=0.004)$. At the beginning of the experiment (T0) we found 32(43), 36(46) and 27(39) phytoplankton genera (morphotypes) into LTF, STF and control respectively; and at the end of the experiment (T4) 24(31), 28(38) and 27(39) genera (morphotypes) were observed into LTF, STF and control. The Shannon diversity index, decreased over time in the mesocosms with fish and did not change significantly in the controls (Fig. 5).

The presence of trout reduced the mean size of phytoplankton with GALD $>30 \mu \mathrm{m}$. The mean size of Peridinium showed no significant difference between treatments at the beginning of the experiments (T0; $\mathrm{P}<0.2896$ ) and between the beginning (T0) and the end of experiments (T4) in controls $(\mathrm{P}<0.1233)$; but it decreased significantly $(\mathrm{P}<0.0001)$ in the treatments with fish. This indicated that large crustacean zooplankton $(C$. brandorffi) grazed on the most abundant algae (GALD $>30 \mu \mathrm{m}$ ) but selected the smaller cells, increasing

Tab. 1. ANOVA for repeated and non-repeated measures of environmental variables and biomass of the phytoplanktonic and zooplanktonic groups of the STF, LTF and control experiments.

\begin{tabular}{|c|c|c|c|c|c|c|c|c|c|}
\hline & \multicolumn{3}{|c|}{ Treatment } & \multicolumn{3}{|c|}{ Time } & \multicolumn{3}{|c|}{ TreatmentxTime } \\
\hline & df & F & $\mathbf{P}$ & df & F & $\mathbf{P}$ & df & F & $\mathbf{P}$ \\
\hline \multicolumn{10}{|c|}{ Environmental variables } \\
\hline DIN & 2 & 19.10 & $0.003 * *$ & 4 & 34.07 & $0.000 * * *$ & 8 & 8.28 & $0.002 * *$ \\
\hline CLORa & 2 & 17.66 & $0.003 * *$ & 4 & 37.20 & $0.001 * * *$ & 8 & 6.01 & $0.034 *$ \\
\hline MO & 2 & 5.11 & $0.051 \bullet$ & 4 & 8.45 & $0.013^{*}$ & 8 & 0.73 & 0.558 \\
\hline $\mathrm{CON}$ & 2 & 4.44 & 0.066 & 4 & 40.25 & $0.000 * * *$ & 8 & 6.06 & $0.000 * * *$ \\
\hline $\mathrm{pH}$ & 2 & 2.05 & 0.210 & 4 & 14.17 & $0.000 * * *$ & 8 & 0.33 & 0.946 \\
\hline TEM & 2 & 0.32 & 0.736 & 4 & 362.58 & $0.000 * * *$ & 8 & 5.82 & $0.000 * * *$ \\
\hline $\mathrm{SO} 2$ & 2 & 0.29 & 0.756 & 4 & 32.94 & $0.000 * * *$ & 8 & 2.60 & $0.033^{*}$ \\
\hline DRP & 2 & 0.24 & 0.793 & 3 & 14.45 & $0.002 * *$ & 6 & 1.60 & 0.257 \\
\hline ALK & 2 & 0.01 & 0.995 & 4 & 5.96 & $0.002 * *$ & 8 & 0.92 & 0.515 \\
\hline \multicolumn{10}{|c|}{ Zooplankton } \\
\hline CRUST & 2 & 38.92 & $0.000 * * *$ & 4 & 84.20 & $0.000^{* * *}$ & 8 & 22.13 & $0.000^{* * *}$ \\
\hline Cbran & 2 & 29.34 & $0.001 * * *$ & 4 & 82.98 & $0.000 * * *$ & 8 & 22.05 & $0.000 * * *$ \\
\hline Tpras & 2 & 26.91 & $0.001 * *$ & 4 & 2.60 & $0.062 \bullet$ & 8 & 3.82 & $0.005^{* *}$ \\
\hline Cquad & 2 & 523.83 & $0.000 * * *$ & 4 & 102.64 & $0.000 * * *$ & 8 & 51.19 & $0.000 * * *$ \\
\hline Sclad & 2 & 2.85 & 0.135 & 4 & 4.24 & $0.010^{* *}$ & 8 & 3.20 & $0.013^{*}$ \\
\hline Nauplii & 2 & 0.70 & 0.533 & 4 & 4.50 & $0.007 * *$ & 8 & 1.15 & 0.367 \\
\hline \multicolumn{10}{|c|}{ Phytoplankton } \\
\hline PHYTO & 2 & 1.96 & 0.222 & 4 & 10.32 & $0.000 * * *$ & 8 & 0.68 & 0.702 \\
\hline GALD $>30$ & 2 & 1.98 & 0.218 & 4 & 10.64 & $0.000 * * *$ & 8 & 0.68 & 0.707 \\
\hline GALD $\leq 30$ & 2 & 1.07 & 0.401 & 4 & 14.52 & $0.003 * *$ & 8 & 0.36 & 0.764 \\
\hline
\end{tabular}

DIN, dissolved inorganic nitrogen; CLORa, chlorophyll a; OM, organic matter, CON, conductivity; TEM, temperature; O2S, oxygen saturation; ALK, alkalinity; CRUS, total zooplankton crustaceans; Cbran, C. Brandorffi; Cquad, C. quadrangular; SClad, small cladocerans; Nauplii, nauplii of copepods; PHYTO, total

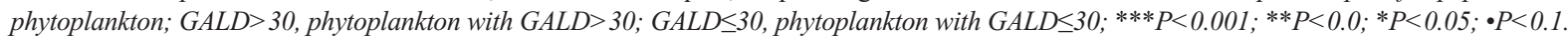


the mean size of algae as Peridinium. When fish fry were introduced, it decreased herbivory pressure on phytoplankton (correlation between BZ:BP and phytoplankton biomass, $0.84, \mathrm{P}<0.001)$, reducing the average size of Peridinium.

\section{DISCUSSION}

Our experimental results supported the hypothesis that juvenile fish have strong effects on the structure of plankton communities that vary depending on the size of both fish and their prey (Fig. 6). These results show that young trout preyed heavily on the largest and most abundant zooplankton species (C. brandorffi), similar to that found by other authors (Hall et al., 1976; Schabetsberger et al., 2009; Tiberti et al., 2014). However, we also found that small crustaceans such as Ceriodaphnia and cyclopoid copepods were preyed upon by trout, in contrast with some other studies (Knapp et al., 2001b; Schabetsberger et al., 2009; Maclennan et al., 2015). The diets of smaller juvenile fish have not previously been characterized as they are usually not caught by gear such as gill nets. Fry can have a distinct impact on the zooplankton compared to larger fish because they are often very numerous and prey on smaller zooplankton (Walls et al., 1990; Ban et
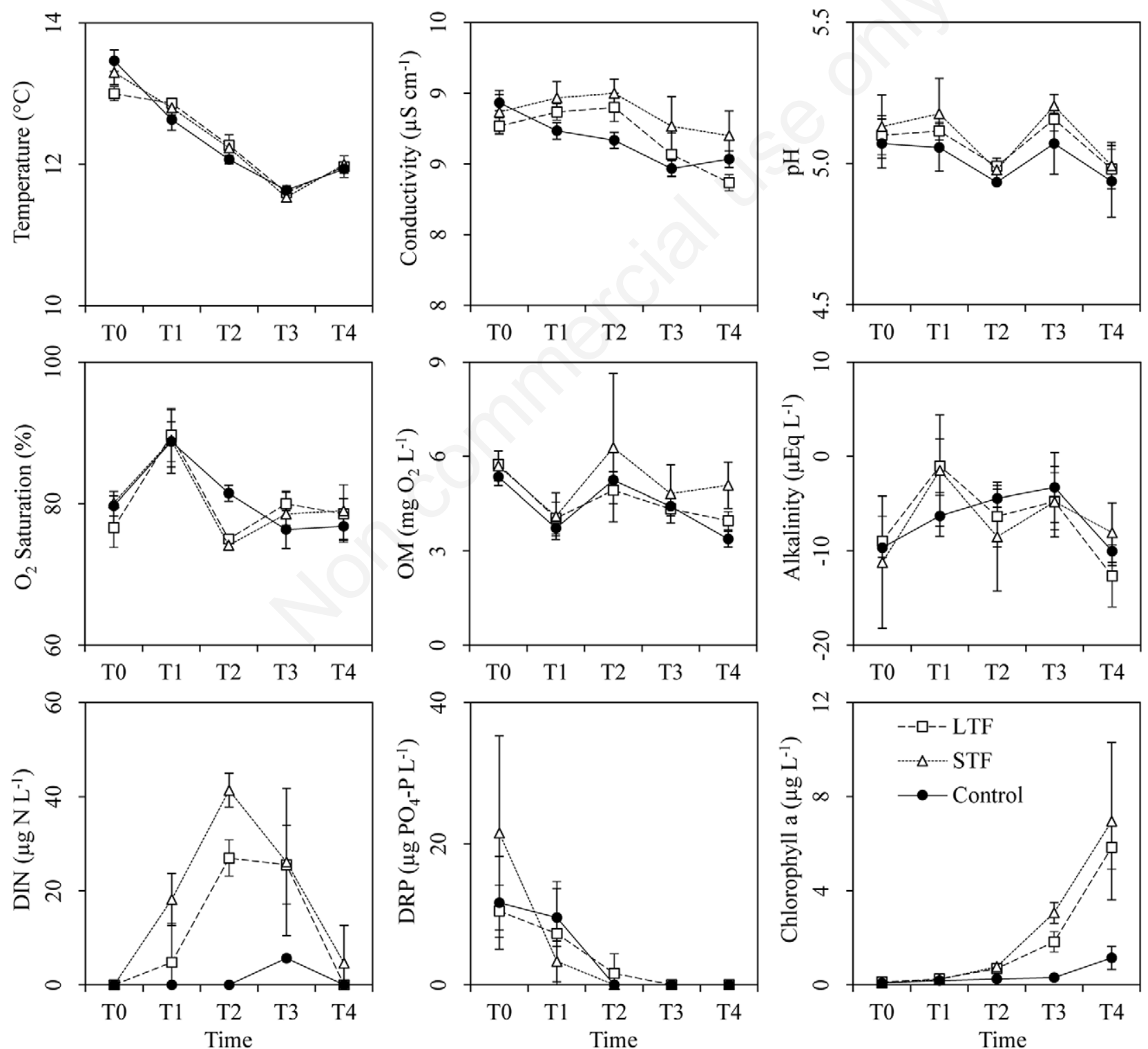

Fig. 2. Changes in environmental variables in the mesocosms with large (LTF) and small trout fry (STF) and control without fishes. The error bars represent the standard deviations of the means of the mesocosms. 
al., 2013). Our results indicate that the feeding behavior of the fish changed in relation to the size (stage of development) of fish. The ability of the planktivorous fish to detect and capture prey depends on factors like abundance, size and mobility of the prey (Brooks and Dodson, 1965; Reiriz et al., 1998; Sánchez-Hernández et al., 2012). In our study the trout fry preferred largest and most abundant zooplankton species according to the size selectivity hypothesis (Brooks and Dodson, 1965; Werner and Hall, 1974; O'Brien et al., 1976). However, C. quadrangula, a smaller but slower crustacean, was also subject to fish predation. Indirect interactions among zooplankton, for instance intraguild predation by copepods on cladocerans, may also explain some of the effects of fish pre- dation on smaller zooplankton taxa. Our data indicate strong cascading effects of juvenile stages of trout on zooplankton in tropical mountain lakes.

Fish predation triggered a trophic cascade effect on chlorophyll $a$ concentration and on the diversity and size structure of phytoplankton, but less evident on algal biomass. The correlation between phytoplankton biomass, calculated from biovolume, and chlorophyll $a$ was weak, likely because the chlorophyll content per volume of phytoplankton are highly variable (Rott, 1978; Kalchev et al., 1996; Felip and Catalan, 2000).

The presence of fish fry caused the decrease in grazing pressure of $C$. brandorffi on phytoplankton with GALD $>30 \mu \mathrm{m}$; nevertheless, the algal biomass did not in-
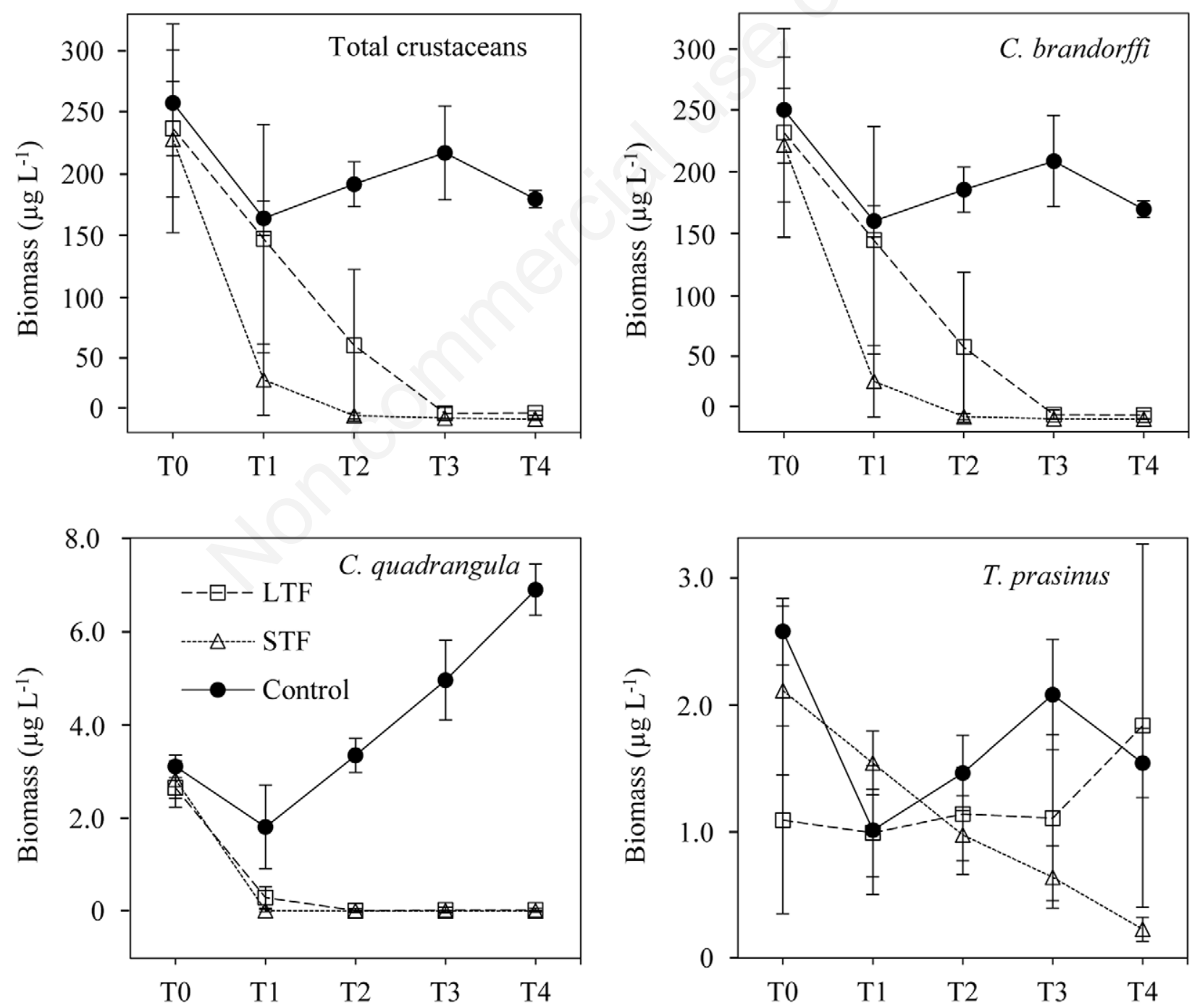

Fig. 3. Changes in crustacean zooplankton biomass in mesocosms with large (LTF) and small trout fry (STF) and controls fishless. The error bars represent the standard deviations of the means of the mesocosms. 
crease significantly in fish treatments compared to the control treatments. The intensity with which zooplankton reduce phytoplankton biomass varies in relation to different factors such as lake trophic status and pelagic food web structure (Vadeboncoeur et al., 2002). Phytoplankton biomass is also regulated by nutrient concentrations (Jeppesen et al., 2005), mainly phosphorus (Gorman et al., 2014) and this was quickly depleted during development of the experiments. The presence of fish had a negative effect on the phytoplankton diversity, reducing the number of taxa, and those who most contributed to diversity were small algae $(\mathrm{GALD} \leq 30 \mu \mathrm{m})$, since most of the biomass of large algae was due to Peridinium. Possibly the increase of the biomass of the large algae affected the competitive relationships within the phytoplankton, which led to a change in the composition of smaller and scarce but more diverse species of algae. Other authors have also documented cascading effects on phytoplankton composition (Ellis et al., 2011; Duggan et al., 2015). Our results indicate shifts in chlorophyll concentration and effect on phytoplankton biomass and species richness.

In Lake Cristalina zooplankton feed mainly on phytoplankton with GALD $>30 \mu \mathrm{m}$. The abundance of herbivores, mainly $C$. brandorffi, the largest and most abundant zooplankter, decreased in trout fry treatments, causing a reduction in grazing pressure and of average size of Peridinium. These results are consistent with the size-efficiency hypothesis (SEH), which postulates that the minimum and maximum size of the food particles ingested by zooplankton depends on body size, and that the larger organisms consume a wider size range of particles (Hall et al., 1976; Cyr and Curtis, 1999;
Humphries, 2007). However, our results conflict with other research where algae with GALD $>30 \mu \mathrm{m}$ are considered less vulnerable or inedible for herbivorous zooplankton (Attayde and Hansson, 2001; Benndorf et al., 2002; Zhao et al., 2016). One reason may be that studies on the size of algae consumed by zooplankton include large cladocerans such as Daphnia (Elser and Goldman, 1991; Zhao et al., 2013), and Cristalina Lake, a tropical oligotrophic high mountain lake, is dominated by a calanoid copepod. The size structure of phytoplankton depends on the species composition of the zooplankton assemblages (Bergquist et al., 1985). Our results indicate that copepods can consume food particles larger than those consumed by cladocerans (Peters and Downing, 1984; Bern, 1994). A high abundance of algae with GALD $>30 \mu \mathrm{m}$ may reflect high herbivore pressure on smaller algae (Litchman et al., 2010). We expected, but did not observe, increased biomass of smaller algae in treatments with trout fry (Fig. 4).

Although the effect of fish may be strong on zooplankton and weak on phytoplankton in oligotrophic lakes (Jeppesen et al., 2000; Magnea et al., 2013), our results indicate strong cascading effects on chlorophyll and appreciable on biomass and diversity of phytoplankton. Cascading effects were observed even though the keystone grazer Daphnia was absent from Cristalina lake, and potentially omnivorous copepods dominated the zooplankton assemblage. In addition, although nutrient limitation likely constrains primary productivity under such oligotrophic conditions, indirect effects of fish predators on phytoplankton mediated by grazers are also important. Fish also increased concentrations of dissolved inorganic
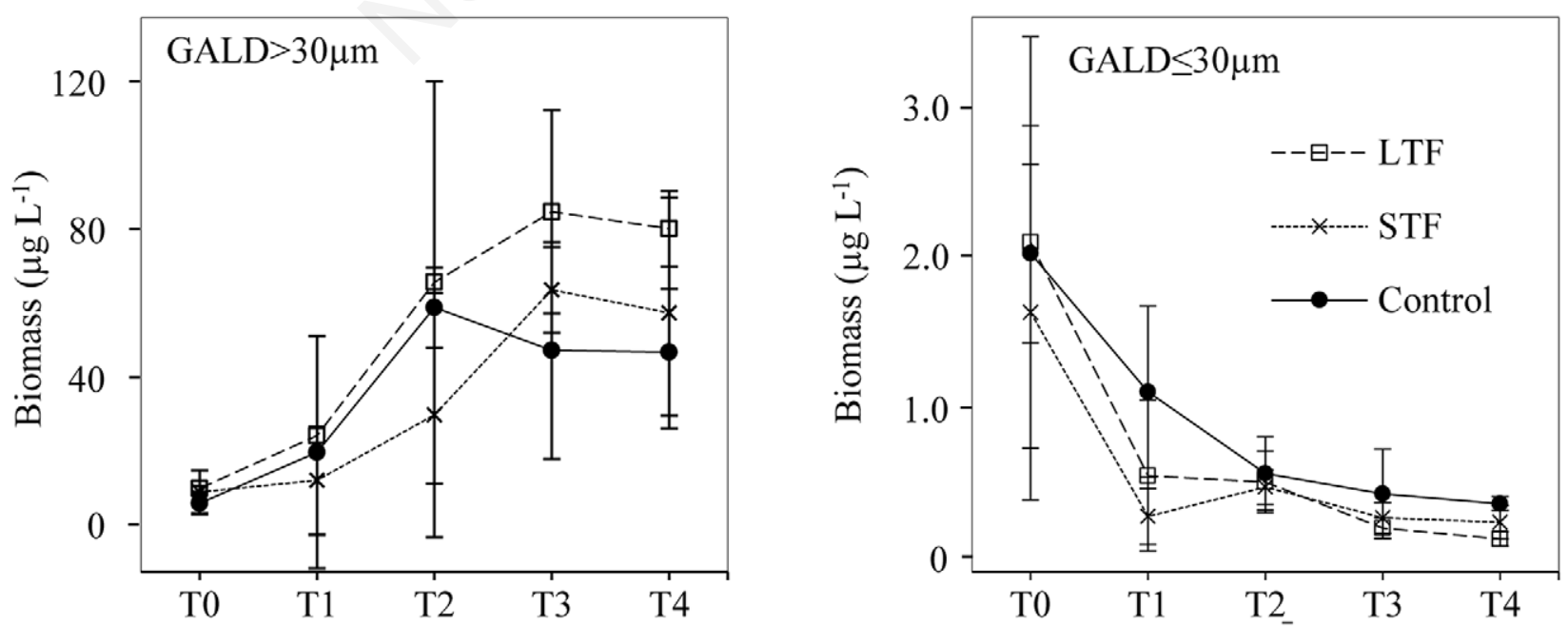

Fig. 4. Changes in phytoplankton biomass in mesocosms with large (LTF) and small trout fry (STF) and controls fishless. The error bars represent the standard deviations of the means of the mesocosms. 
nitrogen, indicating that nutrient excretion may be another mechanism for their effects on phytoplankton.

\section{CONCLUSIONS}

Our results indicate that rainbow trout fry have cascading effects on tropical mountain lakes ecosystems despite the absence of large herbivorous zooplankton such as Daphnia. Our study showed that small changes in the size of trout fry lead to ontogenetic diet shifts with effects on the structure of zooplankton. The younger and newly hatched fishes had stronger effects on zooplankton than slightly larger fishes, and also prey on highly mobile species like T. prasinus. Our results revealed a cascading effect by trout predation on size structure of phytoplankton, and inverse correlations between large zooplankton and chlorophyll $a$, large phytoplankton and richness of algae. These results highlight that the fish introductions, especially juvenile fish, in oligotrophic fishless have strong effects on tropical lake ecosystems, comparable to those observed in temperate lakes.

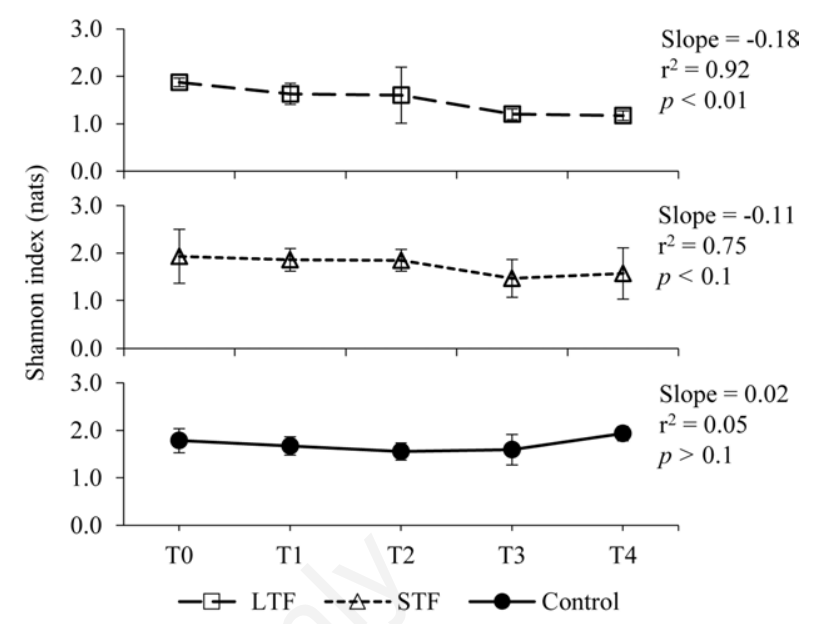

Fig. 5. Changes in phytoplankton diversity in mesocosms with large (LTF) and small (STF) trout fry and in controls fishless over time. The error bars represent the standard deviations of the means of the mesocosms.
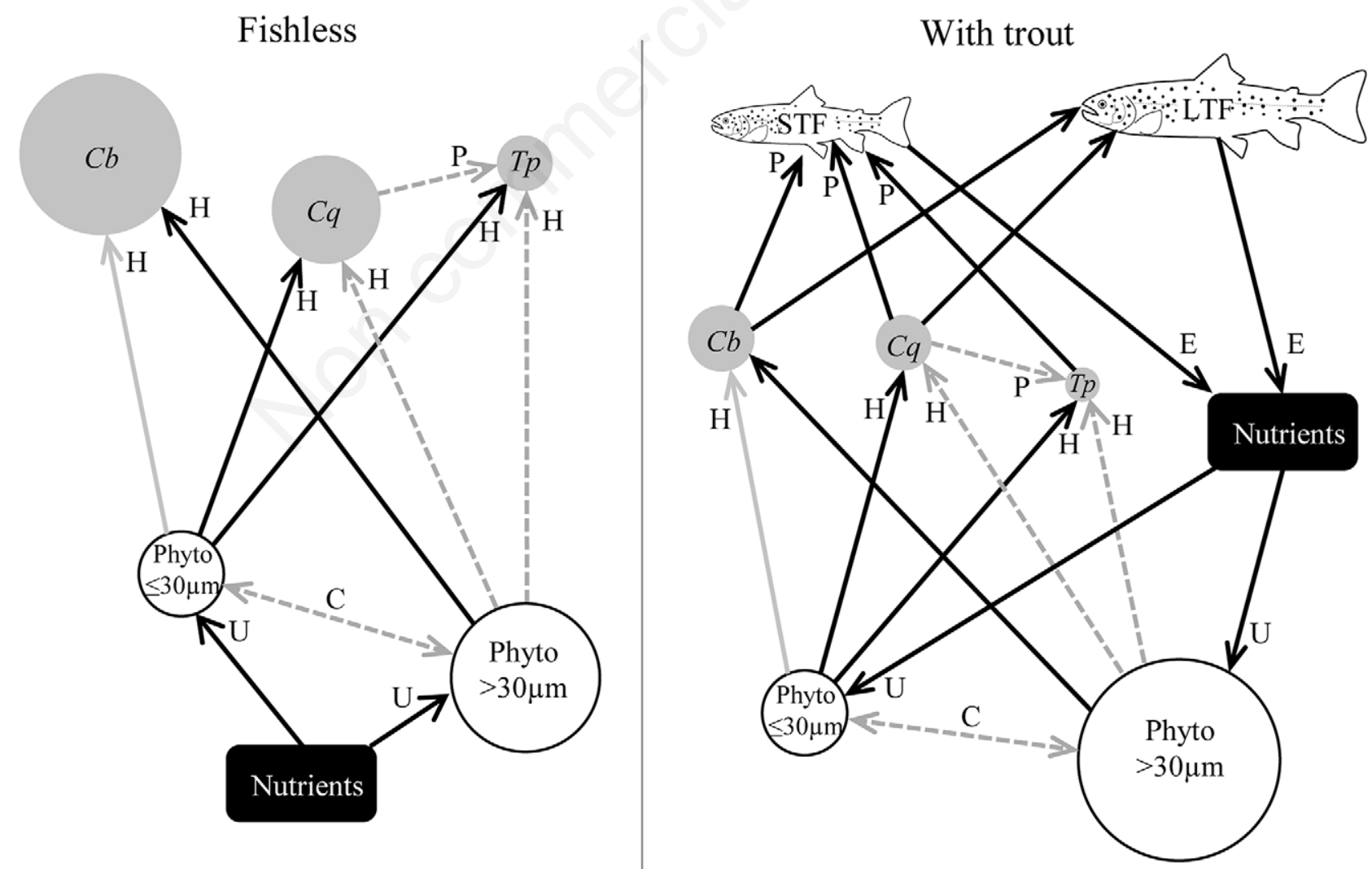

Fig. 6. Trophic relationships in presence-absence of fish. Stronger relationships (continuous black arrows), less strong relationships (continuous gray arrows). Possible relationships (gray arrows discontinuous). The size of the circles is an indicator of abundance. $C b$, C. brandorffi; Tp, T. prasinus; Cq, C. quadrangular; Phyto $>30 \mu \mathrm{m}$, large phytoplankton; Phyto $\leq 30 \mu \mathrm{m}$, small phytoplankton; H, herbivory; P, predation; C, competition; E, excretion; U, uptake. 


\section{ACKNOWLEDGMENTS}

This study was supported by funds from the Empresa Colombiana de Petroleos (ECOPETROL) and the Pedagogical and Technological University of Colombia (UPTC) (Grant 194-2009 and 5211416-2011). We thank to personal of Investigation group 'Manejo Integrado de Ecosistemas y Biodiversidad - XIUÂ' of the UPTC and Neotropical Foundation, in special to Zully Ojeda, who assisted within the fieldwork. We are also grateful to Jonathan Shurin and Salvador Herrando for their valuable comments to improve the manuscript. We thank the $\mathrm{PhD}$ program in Science-Biology at the National University of Colombia for academic training.

\section{REFERENCES}

Acero A, 1977. [Informe sobre la pesca continental y la piscicultura en Colombia].[Article in Spanish]. Informes de Pesca 3:19-36.

Aguilera X, Declerck S, De Meester L, Maldonado M, Ollevier F, 2006. Tropical high Andes lakes: A limnological survey and an assessment of exotic rainbow trout (Oncorhynchus mykiss). Limnologica 36:258-268.

Arellano-P H, Rangel-Ch JO, 2008. [Patrones en la distribución de la vegetación en áreas de páramo de Colombia: heterogeneidad y dependencia espacial].[Article in Spanish]. Caldasia 30:355-411.

Attayde JL, Hansson LA, 2001. The relative importance of fish predation and excretion effects on planktonic communities. Limnol. Oceanogr. 46:1001-1012.

Balon EK, 1984. Reflections on some decisive events in the early life of fishes. T. Am. Fish. Soc. 113:178-185.

Ban S, Makino W, Sakano H, Haruna H, Ueda H, 2013. Annual variation in biomass and the community structure of crustacean zooplankton over 5 years in Lake Toya, Japan. Limnology 14:59-70.

Benndorf JU, Boing W, Koop J, Neubauer I, 2002. Top-down control of phytoplankton: the role of time scale, lake depth and trophic state. Freshwater Biol. 47:2282-2295.

Bergquist AM, Carpenter SR, Latino JC, 1985. Shifts in phytoplankton size structure and community composition during grazing by contrasting zooplankton assemblages. Limnol. Oceanogr. 30:1037-1045.

Bern L, 1994. Particle selection over a broad size range by crustacean zooplankton. Freshwater Biol. 32:105-112.

Blair JM, Hicks BJ, Pitkethley R, Ling N, 2012. Diet of rainbow trout in Lake Rotoiti: an energetic perspective. N. Zeal. J. Mar. Fresh. 46:557-565.

Box GEP, 1954a. Some theorems on quadratic forms applied in the study of analysis of variance problems, I. Effect of inequality of variance in the one-way classification. Ann. Math. Stat. 25:290-302.

Box GEP, 1954b. Some theorems on quadratic forms applied in the study of analysis of variance problems, II. Effects of inequality of variance and of correlation between errors in the two-way classification. Ann. Math. Stat. 25:484-498.
Brett MT, Goldman CR, 1996. A meta-analysis of the freshwater trophic cascade. P. Natl. Acad. Sci. USA 93:7723-7726.

Brooks JL, Dodson SI, 1965. Predation, body size, and composition of plankton. Science 150:28-35.

Budy P, Haddix T, Schneidervin R, 2005. Zooplankton size selection relative to gill raker spacing in rainbow trout. T. Am. Fish. Soc. 134:1228-1235.

Buktenica MW, Girdner SF, Larson GL, Mcintire CD, 2007. Variability of kokanee and rainbow trout food habits, distribution, and population dynamics, in an ultraoligotrophic lake with no manipulative management. Hydrobiologia 574:235-264.

Carmouze JP, 1994. [O metabolismo dos ecossistemas aquáticos: fundamentos teóricos, métodos de estudo e análises químicas].[Book in Portuguese]. Edgard Blücher, São Paulo: 254 pp.

Clesceri LS, Greenberg AE, Eaton AD, 1998. Standard methods for the examination of water and wastewater, 20th ed. American Public Health Association, American Water Works Association, Water Environment Federation.

Crawford SS, Muir AM, 2008. Global introductions of salmon and trout in the genus Oncorhynchus: 1870-2007. Rev. Fish Biol. Fisheries 18:313-344.

Cuatrecasas J, 1996. [Clave provisional de las especies del género Espeletiopsis Cuatrec. (Espeletiinae, Compositae)].[Article in Spanish]. Anales Jard. Bot. Madrid 54:370-377.

Cyr H, Curtis JM, 1999. Zooplankton community size structure and taxonomic composition affects size-selective grazing in natural communities. Oecologia 118:306-315.

Davis MA, 2003. Biotic globalization: does competition from Introduced species threaten biodiversity? BioScience 53:481-489.

Díaz-Piedrahita S, Rodríguez-Cabeza BV, 2008. [Novedades en los géneros Espeletia Mutis ex Humb. \& Bonpl. y Espeletiopsis Cuatrec. (Asteraceae, Heliantheae, Espeletiinae)]. [Article in Spanish]. Rev. Acad. Colomb. Cienc. Exact. Fis. y Nat. 32:455-464.

Donald DB, Vinebrooke RD, Anderson RS, Syrgiannis J, Graham MD, 2001. Recovery of zooplankton assemblages in mountain lakes from the effects of introduced sport fish. Can. J. Fish. Aquat. Sci. 58:1822-1830.

Duggan IC, Wood SA, West DW, 2015. Brown trout (Salmo trutta) removal by rotenone alters zooplankton and phytoplankton community composition in a shallow mesotrophic reservoir. New Zeal. J. Mar. Fresh. 49:356-365.

Dumont HJ, Velde I, Dumont S, 1975. The dry weight estimate of biomass in a selection of Cladocera, Copepoda and Rotifera from the plankton, periphyton and benthos of continental waters. Oecologia 19:75-97.

Elías-Gutiérrez M, Suárez-Morales E, Gutiérrez-Aguirre MA, Silva-Briano M, Granados-Ramírez JG, Garfias-Espejo T, 2008. [Cladocera y Copepoda de las aguas continentales de México].[Book in Spanish]. Universidad Nacional Autónoma de México: 322 pp.

Elmoor-Loureiro LMA, 1997. [Manual de identificação de cladóceros límnicos do Brasil].[Book in Portuguese]. Editora Universa, Universidade Católica de Brasília: 155 pp.

Elser JJ, Goldman CR, 1991. Zooplankton effects on phytoplankton in lakes of contrasting trophic status. Limnol. Oceanogr. 36:64-90.

Ellis BK, Stanford JA, Goodman D, Stafford CP, Gustafson DL, 
Beauchamp DA, Chess DW, Craft JA, Deleray MA, Hansen BS, Carpenter SR, 2011. Long-term effects of a trophic cascade in a large lake ecosystem. P. Natl. Acad. Sci. USA 108:1070-1075.

Felip M, Catalan J, 2000. The relationship between phytoplankton biovolume and chlorophyll in a deep oligotrophic lake: decoupling in their spatial and temporal maxima. J. Plankton Res. 22:91-106.

Gallardo B, Clavero M, Sánchez MI, Vilà M, 2015. Global ecological impacts of invasive species in aquatic ecosystems. Global Change Biol. 22:151-163.

Gaviria S, 1989. The calanoid fauna (Crustacea, Copepoda) of the Cordillera Oriental of the Colombian Andes. Hydrobiologia 178:113-134.

Gliwicz ZM, Rowan MG, 1984. Survival of Cyclops abyssorum tatricus (Copepoda, Crustacea) in alpine lakes stocked with planktivorous fish1. Limnol. Oceanogr. 29:1290-1299.

Gorman MW, Zimmer KD, Herwig BR, Hanson MA, Wright RG, Vaughn SR, Younk JA, 2014. Relative importance of phosphorus, fish biomass, and watershed land use as drivers of phytoplankton abundance in shallow lakes. Sci. Total Environ. 466-467:849-855.

Gran G, 1950. Determination of the equivalence point in potentiometric titrations. Acta Chem. Scand. 4:559-577.

Graynoth E, 1999. Recruitment and distribution of juvenile salmonids in Lake Coleridge, New Zealand. N. Zeal. J. Mar. Fresh. 33:205-219.

Greenhouse SW, Geisser S, 1959. On methods in the analysis of profile data. Psychometrika 24:95-112.

Guisande C, Vaamonde A, Barreiro A, Heine J, 2014. RWizard Software. University of Vigo. Available from: http://www. ipez.es/RWizard

Hall DJ, Threlkeld ST, Burns CW, Crowley PH, 1976. The sizeefficiency hypothesis and the size structure of zooplankton communities. Annu. Rev. Ecol. Syst. 7:177-208.

Haney JF, Hall DJ, 1973. Sugar-coated Daphnia: a preservation technique for Cladocera. Limnol. Oceanogr. 18:331-333.

Hernández J, Ortiz R, Walschburger T, Hurtado A, 1992. [Centros de endemismo en Colombia], p. 175-190. In: G. Halffter (ed.), [La diversidad biológica de iberoamérica].[Book in Spanish]. Instituto de Ecología, AC, Xalapa.

Hickley P, Chare S, 2004. Fisheries for non-native species in England and Wales: angling or the environment? Fisheries Manag. Ecol. 11:203-212.

Hillebrand H, Dürselen CD, Kirschtel D, Pollingher U, Zohary $\mathrm{T}, 1999$. Biovolume calculation for pelagic and benthic microalgae. J. Phycol. 35:403-424.

Hrbáček J, Dvořáková M, Kořínek V, Prochazkova, L, 1961. Demonstration of the effect of the fish stock on the species composition of zooplankton and the intensity of metabolism of the whole plankton association. Int. Verh. Theor. Angew. 14:192-195.

Humphries S, 2007. Body size and suspension feeding, p. 1632. In: A.G. Hildrew, D.G. Raffaelli and R. Edmonds-Brown (eds.), Body size-the structure and function of aquatic ecosystems. Cambridge University Press, Cambridge.

Huynh H, Feldt LS, 1970. Conditions under which mean square ratios in repeated measurements designs have exact F-distributions. J. Am. Stat. Assoc. 65:1582-1589.

Jeppesen E, Lauridsen TL, Mitchell SF, Christoffersen K, Burns $\mathrm{CW}, 2000$. Trophic structure in the pelagial of 25 shallow
New Zealand lakes: changes along nutrient and fish gradients. J. Plankton Res. 22:951-968.

Jeppesen E, Søndergaard M, Jensen J, Havens K, Anneville O, Carvalho L, Coveney MF, Deneke R, Dokulil M, Foy B, Gerdeaux D, Hampton SE, Hilt S, Kangur K, Köhler J, Lammens EHHR, Lauridsen TL, Manca M, Miracle MR, Moss B, Nõges P, Persson G, Phillips G, Portielje R, Romo S, Schelske CL, Straile D, Tatrai I, Willén E, Winder M, 2005. Lake responses to reduced nutrient loading - an analysis of contemporary long-term data from 35 case studies. Freshwater Biol. 50:1747-1771.

Jeppesen E, Søndergaard M, Kanstrup E, Petersen B, Eriksen RB, Hammershøj M, Mortensen E, Jensen JP, Have A, 1994. Does the impact of nutrients on the biological structure and function of brackish and freshwater lakes differ? Hydrobiologia 275:15-30.

Juncos R, Milano D, Macchi PJ, Alonso MF, Vigliano PH, 2011. Response of rainbow trout to different food web structures in northern Patagonia: Implications for growth, bioenergetics, and invasiveness. T. Am. Fish. Soc. 140:415-428.

Kalchev RK, Beshkova MB, Boumbarova CS, Tsvetkova RL, Sais D, 1996. Some allometric and non-allometric relationships between chlorophyll-a and abundance variables of phytoplankton. Hydrobiologia 341:235-245.

Knapp AR, Corn SP, Schindler ED, 2001a. The introduction of nonnative fish into wilderness lakes: good intentions, conflicting mandates, and unintended consequences. Ecosystems 4:275-278.

Knapp RA, Matthews KR, Sarnelle O, 2001b. Resistance and resilience of alpine lake fauna to fish introductions. Ecol. Monogr. 71:401-421.

Kratina P, Greig HS, Thompson PL, Carvalho-Pereira TSA, Shurin JB, 2012. Warming modifies trophic cascades and eutrophication in experimental freshwater communities. Ecology 93:1421-1430.

Kruskal WH, Wallis WA, 1952. Use of ranks in one-criterion variance analysis. J. Am. Stat. Assoc. 47:583-621.

Litchman E, De Tezanos Pinto P, Klausmeier CA, Thomas MK, Yoshiyama K, 2010. Linking traits to species diversity and community structure in phytoplankton. Hydrobiologia 653:15-28

Lowe S, Browne M, Boudjelas S, De Poorter M, 2000. 100 of the world's worst invasive alien species: a selection from the global invasive species database, p. 12. The Invasive Species Specialist Group (ISSG) a specialist group of the Species Survival Commission (SSC) of the World Conservation Union (IUCN).

MacLennan MM, Dings-Avery C, Vinebrooke RD, 2015. Invasive trout increase the climatic sensitivity of zooplankton communities in naturally fishless lakes. Freshwater Biol. 60:1502-1513.

Magnea U, Sciascia R, Paparella F, Tiberti R, Provenzale A, 2013. A model for high-altitude alpine lake ecosystems and the effect of introduced fish. Ecol. Model. 251:211-220.

Mauchly JW, 1940. Significance test for sphericity of a normal n-variate distribution. Ann. Math. Stat. 11:204-209.

Mehner T, Thiel R, 1999. A review of predation impact by $0+$ fish on zooplankton in fresh and brackish waters of the temperate northern hemisphere. Environ. Biol. Fish. 56:169-181.

Miles C, 1942. [Descripción sistemática del "pez graso" del Lago de Tota (Boyacá)].[Article in Spanish]. Caldasia 5:55-58. 
Modenutti BE, Balseiro EG, Cervellini PM, 1993. Effect of the selective feeding of Galaxias maculatus (Salmoniformes, Galaxiidae) on zooplankton of a South Andes lake. Aquat. Sci. 55:65-75

Mora G, Téllez L, Cala P, Guillot G, 1992. [Estudio bioecológico de la ictiofauna del Lago de Tota (BoyacáColombia), con énfasis en la trucha arco iris, Oncorhynchus mykiss].[Article in Spanish]. Rev. Acad. Colomb. Cienc. Exact. Fis. y Nat. 18:409-422.

Nusch EA, 1980. Comparison of different methods for chlorophyll and phaeopigments determination. Arch. Hydrobiol. 14:14-36.

O'Brien WJ, Slade NA, Vinyard GL, 1976. Apparent size as the determinant of prey selection by bluegill sunfish (Lepomis macrochirus). Ecology 57:1304-1310.

Oscoz J, Leunda PM, Campos F, Escala MC, García-Fresca C, Miranda R, 2005. Spring diet composition of rainbow trout, Oncorhynchus mykiss (Walbaum, 1792) in the Urederra River (Spain). Ann. Limnol. - Int. J. Lim. 41:27-34.

Pace ML, Cole JJ, Carpenter SR, Kitchell JF, 1999. Trophic cascades revealed in diverse ecosystems. Trends Ecol. Evol. 14:483-488.

Paggi JC, 1995. [Crustacea Cladocera], p. 909-951. In: E.C. Lopretto and G. Tell (eds.), [Ecosistemas de aguas continentales, metodologías para su estudio].[Book in Spanish]. Ediciones Sur, La Plata.

Peters RH, Downing JA, 1984. Empirical analysis of zooplankton filtering and feeding rates. Limnol. Oceanogr. 29:763-784.

Post DM, Palkovacs EP, Schielke EG, Dodson SI, 2008. Intraspecific variation in a predator affects community structure and cascading trophic interactions. Ecology 89:2019-2032.

Pujoni DGF, Maia-Barbosa PM, Barbosa FaR, Fragoso Jr CR, Van Nes EH, 2016. Effects of food web complexity on topdown control in tropical lakes. Ecol. Model. 320:358-365.

Rangel-Ch JO, Aguilar M, 1995. [Una aproximación sobre la diversidad climática en las regiones naturales de Colombia], p. 25-76. In J.O. Rangel-Ch (ed.), [Colombia Diversidad biotica I].[Book in Spanish]. Universidad Nacional de Colombia, Bogotá.

Reid JW, 1985. [Chave de identificação e lista de referências bibliográficas para as espécies continentais sulamericanas de vida livre da ordem Cyclopoida (Crustacea, Copepoda)].[Article in Portuguese]. Bol. Zool. Univ. S. Paulo 9:17-143.

Reiriz L, Nicieza AG, Brañta F, 1998. Prey selection by experienced and naive juvenile Atlantic salmon. J. Fish Biol. 53:100-114.

Ribeiro Guevara S, Bubach D, Macchi PJ, Vigliano P, Arribére M, Colombo JC, 2006. Rb-Cs ratio as an indicator of fish diet in lakes of the Patagonia, Argentina. Biol. Trace. Elem. Res. 111:97-119.

Rice EW, Baird RB, Eaton AD, Clesceri LS, 2012. Standard methods for the examination of water and wastewater, 22nd ed. American Public Health Association.

Rodier J, 1990. [Análisis de las aguas. Aguas naturales, aguas residuales, aguas de mar].[Book in Spanish]. Ediciones Omega, Barcelona: 1059 pp.

Rodier J, Legube B, Merlet N, 2011. [Análisis de Aguas].[Book in Spanish]. Ediciones Omega, Barcelona: 1584 pp.

Rott E, 1978. [Chlorophyll-a-Konzentration und Zellvolumen als Parameter der Phytoplanktonbiomasse].[Article in German]. Ber. Nat.-Med. Ver. Innsbruck 65:11-21.
Sánchez-Hernández J, Servia MJ, Vieira-Lanero R, Cobo F. 2012. Ontogenetic dietary shifts in a predatory freshwater fish species: the brown trout as an example of a dynamic fish species, p. 271-298. In: H. Türker (ed.), New advances and contributions to fish biology. Veterinary Medicine and Science. InTech.

Sarnelle O, Knapp RA, 2004. Zooplankton recovery after fish removal: limitations of the egg bank. Limnol. Oceanogr. 49:1382-1392.

Sartory D, Grobbelaar J, 1984. Extraction of chlorophyll a from freshwater phytoplankton for spectrophotometric analysis. Hydrobiologia 114:177-187.

Schabetsberger R, Luger MS, Drozdowski G, Jagsch A, 2009. Only the small survive: monitoring long-term changes in the zooplankton community of an Alpine lake after fish introduction. Biol. Invasions 11:1335-1345.

Schindler DE, Knapp RA, Leavitt PR, 2001. Alteration of nutrient cycles and algal production resulting from fish introductions into mountain lakes. Ecosystems 4:308-321.

Shannon CE, Weaver W, 1963. The mathematical theory of communication. University of Illinois Press: $125 \mathrm{pp}$.

Smirnov NN, 1971. [Chydoridae of the world's fauna. Fauna of the USSR].[Book in Russian]. Academy of Sciences of the USSR - Zoological Institute: 644 pp.

Strayer DL, 2010. Alien species in fresh waters: ecological effects, interactions with other stressors, and prospects for the future. Freshwater Biol. 55:152-174.

Sun J, Liu D, 2003. Geometric models for calculating cell biovolume and surface area for phytoplankton. J. Plankton Res. 25:1331-1346.

Tiberti R, Von Hardenberg A, Bogliani G, 2014. Ecological impact of introduced fish in high altitude lakes: a case of study from the European Alps. Hydrobiologia 724:1-19.

Utermöhl H, 1958. [Zur Vervollkommnung der quantitativen Phytoplankton-Methodik].[Article in German]. Mitt. Int. Ver. The 9:1-38.

Vadeboncoeur Y, Vander Zanden MJ, Lodge DM, 2002. Putting the lake back together: reintegrating benthic pathways into lake food web models. BioScience 52:44-54.

Vijverberg J, Dejen E, Getahun A, Nagelkerke LA, 2014. Zooplankton, fish communities and the role of planktivory in nine Ethiopian lakes. Hydrobiologia 722:45-60.

Walls M, Kortelainen I, Sarvala J, 1990. Prey responses to fish predation in freshwater communities. Ann. Zool. Fenn. 27:183-199.

Welcomme RL, 1988. International introductions of inland aquatic species. FAO Fisheries Department, Rome: 318 pp.

Werner EE, Gilliam JF, 1984. The ontogenetic niche and species interactions in size-structured populations. Ann. Rev. Ecol. Syst. 15:393-425.

Werner EE, Hall DJ, 1974. Optimal foraging and the size selection of prey by the bluegill sunfish (Lepomis Macrochirus). Ecology 55:1042-1052.

Zhao S-Y, Sun Y-P, Han B-P, 2016. Top-down effects of bighead carp (Aristichthys nobilis) and Leptodora richardi (Haplopoda, Leptodoridae) in a subtropical reservoir during the winter-spring transition: a mesocosm experiment. Hydrobiologia 765:43-54.

Zhao S-Y, Sun Y-P, Lin Q-Q, Han B-P, 2013. Effects of silver carp (Hypophthalmichthys molitrix) and nutrients on the plankton community of a deep, tropical reservoir: an enclosure experiment. Freshwater Biol. 58:100-113. 